
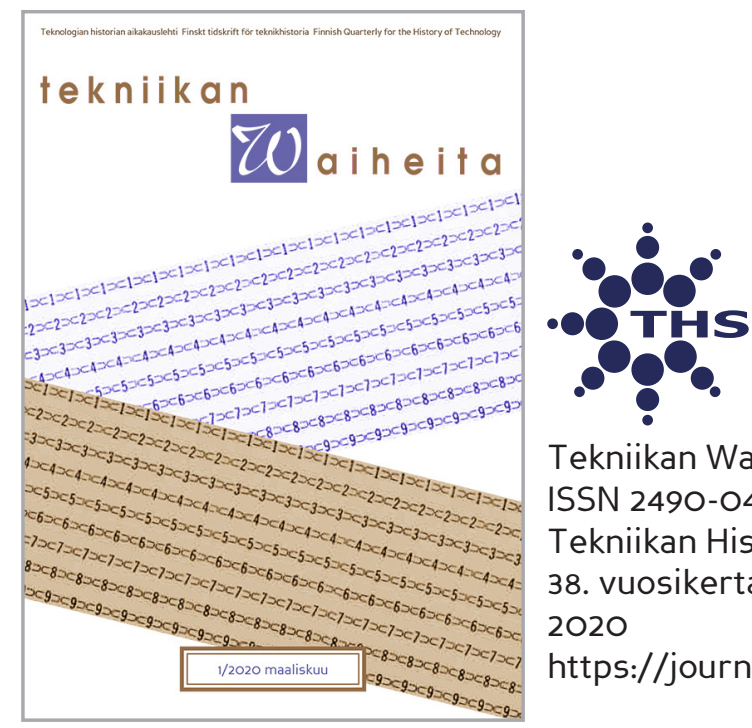

Tekniikan Waiheita

ISSN 2490-0443

Tekniikan Historian Seura ry.

38. vuosikerta:1

2020

https://journal.fi/tekniikanwaiheita

\title{
Insinööriopetuksen kohtalonhetket
}

Heikki Koponen

To cite this article: Heikki Koponen, "Insinööriopetuksen kohtalonhetket" Tekniikan Waiheita 38, no. 1 (2020): 15-17. https://dx.doi.org/10.33355/tw.90673

To link to this article: https://dx.doi.org/10.33355/tw.90673 


\title{
Insinööriopetuksen kohtalonhetket
}

\author{
Heikki Koponen'
}

Uskallan väittää ymmärtäväni hyvin suomalaista korkeakoulukenttää ajavat toimintalogiikat. Olen suorittanut Aalto-yliopistossa DI-tutkinnon, ja opintojeni loppupuolelta saakka toiminut aktiivisesti erilaisissa korkeakoulutuksen kehittämistehtävissä. Vuosina 2015-2020 olen vaikuttanut kansallisessa korkeakoulupolitiikassa, muun muassa Suomen ylioppilaskuntien liiton puheenjohtajana, ja viimeiset pari vuotta suomalaisten tekniikan yliopistojen yhteistyöelin Finnish Institute of Technologyn operatiivisena johtajana. Maaliskuun alussa aloitan työt energiateknologiayhtiö Q Power Oy:n viestintä- ja yhteiskuntasuhdejohtajana.

Korkeakoulukentän kokemukseni myötä olen oppinut, että aika ei välttämättä ole lineaarista, vaan se voi saada myös kehämäisiä piirteitä. Korkeakoulupolitiikassa nimittäin samat teemat ja narratiivit tuntuvat toistuvan vuosikymmenestä toiseen. Suomalainen lehdistö kirjoitteli jo 1900-luvun alussa ylioppilaiden laiskasta rappiosta, ja yhtymäkohdat tämän päivän julkisiin mielikuviin opiskelijoista ovat hymyilyttäviä. Toisaalta esimerkiksi keskustelu korkeakoulujen alueellisesta sijoittumisesta ja merkityksestä hakee kussakin ajassa omat sanoituksensa ja ilmenemismuotonsa, yhtä lailla kuin vaikkapa korkeakouluopetuksen koettu ammatillinen irrelevanssi.

Insinöörikoulutuksen kohdalla eräs monille sukupolville harmaita hiuksia tuottanut kysymys on tasapainoilu koulutuksen yleissivistävien ja ammattiosaamista tuottavien sisältöjen välillä. Yhtäältä insinöörin on osattava riittävästi matematiikka ja fysiikkaa sekä niistä johdettuja soveltavia insinööriasioita voidakseen ratkaista maailmassa tunnistettuja, ja ratkaisuja kaipaavia, ongelmia. Toisaalta tiivis keskittyminen insinööriaineisiin tarkoittaa melkein väistämättä, ettei tutkintorakenteisiin voida juurikaan mahduttaa yleissivistäviä opintoja, kuten historiaa ja filosofiaa, mikä voi kaventaa vaarallisesti insinöörin ymmärrystä ratkaistavien ongelmien luonteesta ja asiayhteydestä.

Tätä tasapainoilua on väännetty ja käännetty tekniikan korkeakouluissa hartaasti. Eri maissa opetussisällöt ovat moninaisista historiallisista syistä rakentuneet hiukan eri asentoihin, mutta yleisesti ottaen on Suomessa tekniikan tutkinnoissa painotettu voimakkaasti insinööriosaamisen sisältöjä yleissivistävien sisältöjen kustannuksella.

Silläkin uhalla, että avataan taas yhtä korkeakoulutuksen ikuisuuskysymystä, on tätä painotusta minusta syytä tarkastella ajassamme hyvin kriittisesti.

Ja miksikö juuri nyt?

Harva lienee enää välttynyt huomaamasta, että olemme globaalisti ekologisen kriisin kanssa kerta kaikkiaan massiivisten vaikeuksien edessä. Eliölajien kiihtyvästi etenevät sukupuutot heikentävät vaarantavasti ihmiskuntaakin ylläpitävää elämän verkkoa, ihmisten

\footnotetext{
${ }^{1}$ Kirjoittaja työskentelee maaliskuusta 2020 alkaen viestintä ja yhteiskuntasuhteiden jotajana Q Power Oy:ssä. Helmikuuhun 2020 asti kirjoittaja työskenteli tekniikan verkostoyliopisto FITech:ssa (Finnish Institute of Technology) COO:na. Vuosina 2015-2020 hän on toiminut kansallisissa korkeakoulupolitiikan vaikuttamistehtävissä.
} 
maankäytön globaali lisääntyminen kaventaa entisestään muun luonnon käytettävissä olevaa tilaa, merten happamoituminen sekä fosforin- ja typenkierron häiriintyminen häiritsevät ekosysteemien kiertokulkuja ja muun muassa aiheuttavat laajojen merialueiden autioitumista, ja ilmastonmuutos on karkaamassa käsistä. Lisäksi sivilisaatiomme on valtavien energiataloudellisten ongelmien ja potentiaalisesti taloudellisen luhistumisen edessä, kun öljyn tuotantokustannus kasvaa helpoimmin hyödynnettävissä olleiden öljyvarantojen nopeasti ehtyessä.

Näiden tutkimuksessa vahvistettujen tosiasioiden äärelle on syytä pysähtyä tuokioksi. Tällaisia uhkia ei voi sivuuttaa ikään kuin yhtenä asiana muiden joukossa, vaan kyse on ihmisen ja miljoonien muiden lajien olemassaoloa uhkaavan mittakaavan asioista. Jos emme onnistu pysäyttämään käynnistämiemme kehityskulkujen etenemistä, voi sivilisaatiollemme käydä kuin Rooman valtakunnalle, Pääsiäissaaren kansalle tai mayoille - meitä voi odottaa romahdus.

Teknologia ja insinöörit ovat näytelleet ratkaisevaa roolia, kun ihmiskunta on opetellut viimeisten muutaman tuhannen vuoden aikana hyödyntämään luonnonvaroja entistä tehokkaammin. Insinööri tai insinöörinmielinen kehitti ensimmäiset maataloustyökalut. Insinööriajattelua tarvittiin, kun ensimmäinen höyrykone kehitettiin ja kun öljyä opeteltiin poraamaan maankuoresta. Teknologia on singonnut ihmiskunnan valtavalle taloudellisen toimeliaisuuden, materiaalisen elintason ja väestön kasvun polulle, ja teknologian kehittämisen yhteydessä tehdyt valinnat ovat suurelta osin muovanneet maailmastamme nykyisenkaltaisen.

Insinöörit ovat juuri nyt kaikkien aikojen suurimman teknologiahaasteen edessä. Meidän pitää muutaman vuoden sisällä rakentaa muun luonnon kanssa tasapainoisessa suhteessa elävä yhteiskunta, jos haluamme koettaa välttää muinaisten sivilisaatioiden kohtalon. Äärimmäisen vahvojen polkuriippuvuuksien ja systeemisen hitauden vallitessa pitää pystyä pysäyttämään eliöiden massasukupuutto ja turvaamaan ainakin yhteiskuntien perustoiminnot jälkifossiilisessa ajassa.

Rohkenen sanoa kenttää läheltä seuranneena, että nykyisten haasteiden mittakaava ei heijastu tekniikan korkeakoulutukseen lähes mitenkään. Koulutamme asiayhteydelleen sokeita insinöörejä, kun meidän pitäisi auttaa heitä ymmärtämään ja tunnistamaan edessä olevia ongelmia riittävän monitahoisesti ja syvällisesti.

Ikuisuuskysymys tai ei, on aika palata piirustuspöydälle tekniikan tutkintosisältöjen kanssa. Silläkin uhalla, että insinöörisubstanssi kärsisi ja sen haltuun ottamiseen työelämässä menisi nykyistä pidempään, on insinöörien opittava korkeakoulussa ymmärtämään maailman tilaa ja teknologian toimintaympäristöä. Tekniikan filosofia ja historia olisivat prioriteettilistan kärjessä, ja lisäksi suuren osan olisi syytä opiskella ainakin ekologian perusteita. Selvää on, että nykyinen koulutuksen resepti ei ole riittävä.

Uusiutumistarpeen mittakaava ja aikataulu ovat tietenkin täysin kohtuuttomia. Toisaalta, jos nyt epäonnistumme, kannattaa tekniikan historian sijasta tutkintotavoitteisiin alkaakin sisällyttää Rooman historiaa vuosina 300-600 jaa. Mikä nyt sitten on kohtuutonta. 